\title{
Evidence of a dual histogenetic pathway of sacrococcygeal teratomas
}

Robert E. Emerson, MD ${ }^{1}$, Chia-Sui Kao, $\mathrm{MD}^{3}$, John N. Eble, MD ${ }^{1}$, David J. Grignon, MD ${ }^{1}$, Mingsheng Wang, $\mathrm{MD}^{1}$, Shaobo Zhang, $\mathrm{MD}^{1}$, Xiaoyan Wang, $\mathrm{MD}^{1}$, Rong Fan, $\mathrm{MD}^{1}$, Timothy A. Masterson, $\mathrm{MD}^{2}$, Lawrence M. Roth, $\mathrm{MD}^{1}$, Liang Cheng, $\mathrm{MD}^{1,2}$

From ${ }^{1}$ Department of Pathology and Laboratory Medicine, ${ }^{2}$ Department of Urology, Indiana University School of Medicine, Indianapolis, USA; ${ }^{3}$ Department of Pathology, Stanford University Medical Center, Stanford, CA, USA.

Running Head: Dual Histogenesis of Sacrococcygeal Teratomas

Key Words: Germ cell tumor, testis, sacrococcygeal teratoma, molecular genetics, histogenesis, isochromosome $12 \mathrm{p}$

Total number of text pages, 17; Number of tables, 2; Number of figures, 2.

Address correspondence and reprint requests to Liang Cheng, M.D., Department of Pathology and Laboratory Medicine, Indiana University School of Medicine, 350 West $11^{\text {th }}$ Street, IUHPL Room 4010, Indianapolis, IN 46202, USA. Telephone: 317-491-6442; Fax: 317-4916419; E-mail: liang_cheng@yahoo.com

This is the author's manuscript of the article published in final edited form as:

Emerson, R. E., Kao, C.-S., Eble, J. N., Grignon, D. J., Wang, M., Zhang, S., ... Cheng, L. (2017). Evidence of a dual histogenetic pathway of sacrococcygeal teratomas. Histopathology, 70(2), 290-300. https://doi.org/10.1111/his.13062 


\begin{abstract}
Aims: Sacrococcygeal teratomas are rare tumors that occur most frequently in neonates, although adult cases also occur. Molecular pathogenesis of these tumors and long term outcome is uncertain.
\end{abstract}

Methods and results: Fifty four sacrococcygeal teratoma specimens from 52 patients were identified and available follow up information was obtained. Fluorescent in situ hybridization analysis was performed to identify $\mathrm{i}(12 \mathrm{p})$ abnormalities on paraffin blocks of the tumor. Among the 48 pediatric patients, there were 44 teratomas and 4 tumors with teratoma and yolk sac tumor ( 1 of which also had primitive neuroectodermal tumor). The teratomas included 37 mature teratomas and 11 immature teratomas (4 grade 1, 2 grade 2, and 5 grade 3). The 44 teratomas lacking a yolk sac tumor component were all negative for $\mathrm{i}(12 \mathrm{p})$. The 4 tumors with a yolk sac tumor component were all positive for $\mathrm{i}(12 \mathrm{p})$. The 4 adult cases all lacked nonteratomatous germ cell tumor components, immature elements, and i(12p). Follow up information was available for 32 patients. Two patients with teratoma had recurrence, but were alive with no evidence of disease after long-term follow up. One patient with teratoma and yolk sac tumor had recurrence 7 months after resection. The other patients were alive with no evidence of disease at last follow up.

Conclusions: Our data suggest that pediatric sacrococcygeal teratomas should be considered as two distinct groups with a divergent histogenetic pathway. Prognosis of these tumors are excellent, despite rare recurrence.

Word counts: 237 


\section{Introduction}

Extragonadal germ cell tumors (GCTs) are rare tumors and accounting for $1-6 \%$ of all GCT cases. ${ }^{1-5}$ Extragonadal GCTs are thought to arise from germ cell precursors that remain along paths of embryonic migration and form tumors in the sacrococcygeal region, retroperitoneum, mediastinum, or other sites. ${ }^{4}$ Although the morphologic appearances are analogous to those in the gonads, the frequency of GCT types and patient distribution are different. The most common extragonadal GCT location in adults is the mediastinum, whereas the sacrococcygeal region and central nervous system are more common sites in children. ${ }^{6-10}$ The behavior is dependent on the combination of patient age, histology type, anatomic site, and clinical stage. ${ }^{4}$

Pediatric sacrococcygeal teratomas most often occur in neonates. Benign behavior is observed in most cases, although metastatic disease has been reported in a fraction of cases. The presence of immature elements in neonatal teratoma is not associated with malignant behavior, but the presence of a nonteratomatous component (yolk sac tumor and/or embryonal carcinoma) is considered evidence of malignant potential and an indication for three-agent cisplatin-based chemotherapy, ${ }^{11,12}$ although patients with $\alpha$-fetoprotein and $\beta$-human chorionic gonadotropin measurements that return to normal following surgery have been followed without chemotherapy ("watch and wait" approach) by some groups. ${ }^{13-15}$ In the absence of nonteratomatous elements, local recurrence may occur, but up to $100 \%$ long term survival has been described in sacrococcygeal teratomas, even in the presence of immature teratoma. ${ }^{16}$ Very rare sacrococcygeal teratomas may recur as YST, but this may represent inadequate histologic sampling of the primary tumor. ${ }^{17,18}$ Sacrococcygeal tumors with a yolk sac tumor component have, even when metastatic, a relatively good prognosis with chemotherapy. ${ }^{13,15}$ 
Adult sacrococcygeal teratomas are very rare, with fewer data regarding prognosis, but the surgical treatment of adult sacrococcygeal teratoma has recently been discussed. ${ }^{19}$ Metastasis was observed in 3 patients in a series of 26 cases $(12 \%)$, exclusively in women. ${ }^{19}$ Associated somatic-type malignancies are associated with poor prognosis. ${ }^{19,20}$ Somatic-type carcinomas include adenocarcinoma, adenosquamous carcinoma, and low-grade neuroendocrine carcinoma. ${ }^{19}$

The isochromosome $12 \mathrm{p}$ abnormality is typical of postpubertal testicular germ cell tumors, but is lacking in germ cell lesions with expected benign behavior, such as pediatric testicular teratoma and ovarian mature cystic teratoma. Malignant GCTs in postpubertal patients, regardless of location, often have isochromosome $\mathrm{i}(12 \mathrm{p})$. $^{21-26}$ However, the same genetic abnormality is extremely rare in pediatric cases, even those with yolk sac tumor. ${ }^{21,27,28}$ Instead, the genetic alterations in malignant GCTs of prepubertal patients are frequently gains of chromosomes 1q, 3, or 20q and loss of chromosomes $1 \mathrm{p}$, 4q, or $6 \mathrm{q} .^{29-31}$

Sacrococcygeal teratoma is the most common GCT of neonates and rarely occurs in adults, ${ }^{16,20,32,33}$ yet studies of their i(12p) status are extremely limited except for one recent study. ${ }^{16}$ We investigated the i(12p) status of a large number of primary sacrococcygeal teratomas in both children and adults, including cases with malignant germ cell tumor elements (primitive neuroectodermal tumor and yolk sac tumor).

\section{Materials and Methods}

A computer-based text search of the surgical pathology files of Indiana University was conducted for "sacrococcygeal" and "teratoma" from 1990 to 2014, and we identified all specimens with paraffin blocks permitting the investigation of chromosomal $12 \mathrm{p}$ abnormalities 
by fluorescence in situ hybridization (FISH). These included 4 specimens from adult patients and 50 specimens from 48 pediatric patients. Clinical information including patient sex, age, duration of available follow up, and patient status at last follow up was obtained. All hematoxylin and eosin-stained sections of the tumors were reviewed by two pathologists (CK and LC) to confirm the diagnosis of teratoma and evaluate the following: histologic grade of teratoma using the same grading system as that used for ovarian teratomas and presence of malignant GCT. ${ }^{34,35}$

FISH testing was performed as previously described. ${ }^{36}$ The slides were deparaffinized with two 15-minute washes of xylene, followed by two 10-minute washes of absolute alcohol. The slides were then air-dried in a fume hood. The slides were treated in $0.1 \mathrm{mM}$ citric acid ( $\mathrm{pH}$ 6.0; Zymed, Carlsbad, CA) at $95^{\circ} \mathrm{C}$ for $10 \mathrm{~min}$, rinsed in distilled water for $3 \mathrm{~min}$, and washed with $2 \mathrm{x}$ SSC for $5 \mathrm{~min}$. Digestion of the tissue was performed by applying $0.4 \mathrm{ml}$ of pepsin $(5 \mathrm{mg} / \mathrm{ml}$ in $0.01 \mathrm{~N} \mathrm{HCl}$ in $0.9 \% \mathrm{NaCl})$ (Sigma, St Louis, $\mathrm{MO}$ ) at $37^{\circ} \mathrm{C}$ for $40 \mathrm{~min}$. The slides were rinsed with distilled water for $3 \mathrm{~min}$, and washed again with 2 x SSC for $5 \mathrm{~min}$, and then air-dried. Dual color FISH was performed by using a mixture of Spectrum Orange labeled centromeric alpha satellite DNA probe (CEP12) and green labeled RP11-267D19 5-Fluorescein (12p11.21) DNA probes for chromosome 12p. Both of the probes were from Vysis (Downers Grove, IL) and were diluted with tDenHyb2 (Insitus, Albuquerque, NM) in a ratio of 1:50 and 1:20, respectively. Five microliters of diluted probes were added to the slide in the reduced light condition, slides were covered with a coverslip, and were sealed with rubber cement. Denaturation was achieved by incubating the slides at $75^{\circ} \mathrm{C}$ for 10 minutes in a humidified box, then the slides were hybridized at $37^{\circ} \mathrm{C}$ overnight. The coverslips were removed and the slides were washed extensively twice with $45^{\circ} \mathrm{C}$ prewarmed $0.1 \mathrm{X} \mathrm{SSC} / 1.5 \mathrm{~mol} / \mathrm{L}$ urea, for 20 minutes for each, followed by a wash with $2 \mathrm{X}$ SSC for 20 minutes and $2 \mathrm{X}$ SSC/0.1\% NP40 for 10 
minutes at $45^{\circ} \mathrm{C}$. The slides were further washed with room temperature $2 \mathrm{X}$ SSC for 5 minutes. The slides were air-dried and counterstained with $10 \mu \mathrm{L}$ of 4,6-diamidino-2-phenylindole (DAPI AntifadeInsitus). The slides were covered and sealed with nail polish. The slides were examined using a Zeiss Axioplan 2 microscope with the following filters: SP-100 DAPI, FITC MF-101 for Spectrum Green (12p) and Gold 31003 for Spectrum Orange (CEP12) from Chroma (Brattleboro, VT). The images were acquired with a CCD camera and analyzed with MetaSystem Isis software (Belmont, MA). Five sequential focus stacks with $0.4-\mu \mathrm{m}$ intervals were acquired and then integrated into a single image in order to reduce thickness-related artifacts. From each tumor section, 100 nuclei were scored for signals from CEP12 (red) and 12p (green) under the fluorescence microscope with 1,000X magnification, and the ratio between green and red signals was subsequently calculated. We analyzed the spatial distribution of the green and red signals to detect the specific patterns of signal aggregation consistent with i(12p), as previously reported. ${ }^{37}$ The quantitative criteria to determine $12 p$ overrepresentation have been described previously. ${ }^{37}$ A classical seminoma specimen was used as a positive control for FISH analyses. Lymphocyte and stromal nuclei from the same tumor were used as normal controls for each tumor. In addition, we analyzed six cases of skin punch biopsies from patients without a history of germ cell tumors as negative controls.

\section{Results}

A total of 50 cases from 48 neonates, infants, and children ( 2 recurrent cases from 2 different patients) were identified. Thirty-four cases were from female (F) patients and 14 from male $(\mathrm{M})(\mathrm{F}: \mathrm{M}$ ratio $=2.4: 1)$. Patient age ranged from 0 days -8 years (median, 2 weeks). Follow up information was available in 30 patients (range: 4-254 months; mean, 8.9 years), and 
all were alive with no evidence of disease with the exception of one who was alive but disease status unknown.

Among the 48 pediatric patients, there were 44 teratomas and 4 tumors consisting of teratoma and yolk sac tumor ( 1 of which also had primitive neuroectodermal tumor). The teratomas included 37 mature teratomas and 11 immature teratomas ( 4 grade 1, 2 grade 2, and 5 grade 3$)$. The 44 teratomas lacking a yolk sac tumor component were all negative for i(12p)

(Figure 1). The 4 tumors with a yolk sac tumor component were all positive for i(12p) (Figure 2).

A total of four adult cases from 3 females and 1 male were identified $(\mathrm{F}: \mathrm{M}$ ratio $=3: 1)$. Patient age ranged from 22-50 years (median, 35 years). Follow up information was available in 2 patients, and both were alive with no evidence of disease at 82 and 180 months, respectively. None of these patients had a documented history of teratoma in childhood, and all cases lacked nonteratomatous germ cell tumor components, immature elements, and $\mathrm{i}(12 \mathrm{p})$.

Follow up information was, therefore, available for 32 patients. Two patients with teratoma had recurrence, but were alive with no evidence of disease after long-term follow up. One patient with teratoma and yolk sac tumor had recurrence 7 months after resection. The other patients were alive with no evidence of disease at last follow up.

A detailed clinicopathologic summary of all 54 cases including their $i(12 p)$ status is provided in Tables 1 and 2 .

\section{Discussion}

Sacrococcygeal teratomas occurring in adults are rare, and there have been limited studies on the $\mathrm{i}(12 \mathrm{p})$ status of sacrococcygeal teratomas, including those with malignant GCT 
elements. We therefore investigated the $\mathrm{i}(12 \mathrm{p})$ status of a large series of both prepubertal and postpubertal sacrococcygeal teratomas, some including yolk sac tumor and primitive neuroectodermal tumor, and correlated the findings with available long-term clinical follow up.

The majority $(88 \%)$ of our sacrococcygeal teratomas occurred in infants $(<1$ year) with a female predominance ( $\mathrm{F}: \mathrm{M}=2.4: 1$, or $71 \%$ among the pediatric cases). These findings are similar to large American, ${ }^{13}$ British, ${ }^{15}$ and Japanese ${ }^{17}$ series of pediatric sacrococcygeal GCT cases, in which $74 \%$ (of 126 patients), $80 \%$ (of 51 patients), and $75 \%$ (of 289 patients) were girls. There were 35 mature teratomas (lacking a yolk sac tumor component, 73\%), 9 immature teratomas (lacking another component, 19\%), and 4 teratomas with a yolk sac tumor component $(8 \%)$. These findings are similar to those reported in the largest of these series, Yoshida, et al. (67\% mature teratoma, $16 \%$ immature teratoma, and $17 \%$ with yolk sac tumor). ${ }^{17}$

All four pediatric cases with yolk sac tumor (including one which also had a primitive neuroectodermal tumor component) displayed i(12p). The other 44 pediatric cases (including 35 mature teratomas and 9 immature teratomas) lacked $i(12 p)$. Three of the 30 pediatric cases with follow up (10\%) had recurrence, a percentage very similar to the $8.7 \%$ reported by Yoshida, et al. $^{17}$

All four adult cases were negative for $i(12 p)$ and neither of the 2 patients with follow up had recurrence. As a whole, regardless of patient age, the presence of malignant GCT components, or $\mathrm{i}(12 \mathrm{p})$ status, all patients except for one were alive without evidence of disease at time of last follow up (mean, 9.4 years).

The occurrence of teratomas in the sacrococcygeal region, representing approximately $40 \%$ of all teratomas, is not well understood, but may relate to the presence of stem cells. Evidence for this includes the expression of the stem cell markers NANOG, OCT4, SSEA-4, and 
nestin in these tumors as well as the high risk of recurrence if the coccyx (thought to harbor associated stem cells) is not removed along with the tumor. ${ }^{38}$ These tumors have been believed to arise from the embryonic tail bud, ${ }^{38}$ but the presence of foregut-derived structures such as respiratory epithelium has been cited as arguing against this interpretation. ${ }^{39}$ Sacrococcygeal teratomas most commonly occur in neonates and infants and studies consistently show a female predominance. ${ }^{11,13,15}$ The reason for the female predominance has not been determined, but might result from later sex-specific differentiation of the caudal mesenchymal tissue including the vertebral column and the pelvic skeleton in the embryo. ${ }^{38}$ Occasional examples of these tumors have been familial with known or suspected mutations, including patients with Currarino Syndrome, thought to involve the HLXB9 gene, ${ }^{40}$ or with other genetic associations such as partial trisomy $3 q$ with Cornelia de Lange Syndrome-like phenotype. ${ }^{41}$ Most of the patients, however, do not have a known genetic abnormality.

The frequency of a malignant component within a sacrococcygeal teratoma is related to patient age, with $1.5 \%$ of tumors from newborns containing a malignant component compared to nearly $40 \%$ of tumors from children older than 1 year. ${ }^{18}$ It has been suggested that yolk sac tumor may occur in sacrococcygeal teratoma as a form of tumor progression. ${ }^{42}$ This seems to be true for the wide variety of somatic tumors that may arise in sacrococcygeal GCTs, including recently reported pediatric cases with sarcoma, ${ }^{43}$ nephroblastic elements, ${ }^{44}$ peripheral primitive neuroectodermal tumor, ${ }^{40}$ malignant ependymoma component, ${ }^{45}$ neuroblastoma, ${ }^{46}$ and malignant steroidogenic tumor ${ }^{47}$ and adult cases with neuroendocrine carcinoma, ${ }^{48}$ adenocarcinoma, ${ }^{49}$ and intestinal-type mucinous neoplasm which recurred as disseminated intraperitoneal disease with pseudomyxoma peritonei. $^{50}$ 
Testicular teratomas may be behaviorally and pathogenetically separated into two broad groups: prepubertal teratomas with typically benign behavior and postpubertal teratomas that are typically components of malignant germ cell tumors. The prepubertal teratomas lack i(12p) abnormalities and are therefore thought to arise from germ cells that are cytogenetically normal, at least in terms of $12 p$ amplification. ${ }^{28,51}$ The $\mathrm{i}(12 \mathrm{p})$ abnormality or other $12 \mathrm{p}$ amplification is a nearly constant finding in adult testicular GCTs including pure teratoma, ${ }^{51}$; however occasional benign postpubertal testicular teratomas lacking $12 \mathrm{p}$ amplification exist. ${ }^{52}$

Ovarian teratomas without and with nonteratomatous elements similarly appear to represent two pathogenetically distinct categories. ${ }^{36}$ Ovarian teratomas lack i(12p) abnormalities, even if immature teratoma is present, unless a nonteratomatous germ cell component is present. $^{28,36}$ Ovarian teratoma with associated yolk sac tumor and/or embryonal carcinoma will frequently contain $\mathrm{i}(12 \mathrm{p})$ in both the teratoma and nonteratomatous components. ${ }^{36}$

It seems reasonable to speculate that sacrococcygeal teratomas similarly may be divided into two pathogenetically distinct categories, but previously few data concerning $\mathrm{i}(12 \mathrm{p})$ status were available. Using classical cytogenetic analysis, no chromosome 12 abnormalities were noted in 18 pediatric sacrococcygeal teratomas, including cases with immature teratoma but no nonteratomatous component ( 3 cases) and cases with nonteratomatous components $(6$ cases $) .{ }^{28} \mathrm{~A}$ series of 14 pediatric and 5 adult sacrococcygeal teratomas with i(12p) analysis by FISH was recently reported by Gurda, et al. ${ }^{16}$ In that study, tumors with associated malignant germ cell tumor (yolk sac tumor) were excluded, but 3 of the pediatric cases had immature elements. While recurrence was observed in 3 pediatric cases and 4 adult cases, no mortality was documented with a median follow up of 6 years. Thirteen of these cases ( 9 pediatric and 4 adult) had FISH analysis performed and none of the cases had an i(12p) abnormality. 
Our findings confirm the absence of $\mathrm{i}(12 \mathrm{p})$ in both pediatric and adult sacrococcygeal teratoma cases, unless an associated malignant GCT component is present. Only 1 tumor with immature teratoma was analyzed for $\mathrm{i}(12 \mathrm{p})$ in the previous study ${ }^{16}$ and we have confirmed the absence of $\mathrm{i}(12 \mathrm{p})$ in 9 additional cases of teratoma with an immature component but no malignant germ cell component.

The $\mathrm{i}(12 \mathrm{p})$ abnormality was not observed in the 4 adult sacrococcygeal teratomas. The $\mathrm{i}(12 \mathrm{p})$ abnormality was detected in $8 \%(4 / 44)$ of pediatric sacrococcygeal germ cell tumors, but only in those with a nonteratomatous component. This is similar to the findings in ovarian teratomas with and without a nonteratomatous component. These cytogenetic findings suggest that pediatric sacrococcygeal teratomas should be considered as two distinct groups, those with and those without other components, and that each group has a distinct molecular pathogenesis.

\section{Disclosure/conflict of interest}

The authors declare no conflict of interest. 


\section{References:}

1. Collins DH, Pugh RC. Classification and frequency of testicular tumours. Br J Urol 1964;36;SUPPL:1-11.

2. Nichols CR, Saxman S, Williams SD et al. Primary mediastinal nonseminomatous germ cell tumors. A modern single institution experience. Cancer 1990;65;1641-1646.

3. Hainsworth JD, Greco FA. Extragonadal germ cell tumors and unrecognized germ cell tumors. Semin Oncol 1992;19;119-127.

4. McKenney JK, Heerema-McKenney A, Rouse RV. Extragonadal germ cell tumors: A review with emphasis on pathologic features, clinical prognostic variables, and differential diagnostic considerations. Adv Anat Pathol 2007;14;69-92.

5. Stang A, Trabert B, Wentzensen $\mathrm{N}$ et al. Gonadal and extragonadal germ cell tumours in the united states, 1973-2007. Int J Androl 2012;35;616-625.

6. Harms D, Janig U. Germ cell tumours of childhood. Report of 170 cases including 59 pure and partial yolk-sac tumours. Virchows Arch A Pathol Anat Histopathol 1986;409;223-239. 7. Nichols CR. Mediastinal germ cell tumors. Clinical features and biologic correlates. Chest 1991;99;472-479.

8. Schneider DT, Calaminus G, Reinhard H et al. Primary mediastinal germ cell tumors in children and adolescents: Results of the german cooperative protocols makei 83/86, 89, and 96. $J$ Clin Oncol 2000;18;832-839.

9. Harms D, Zahn S, Gobel U, Schneider DT. Pathology and molecular biology of teratomas in childhood and adolescence. Klin Padiatr 2006;218;296-302. 
10. De Backer A, Madern GC, Pieters R et al. Influence of tumor site and histology on longterm survival in 193 children with extracranial germ cell tumors. Eur J Pediatr Surg 2008;18;16.

11. Calaminus G, Schneider DT, Bokkerink JP et al. Prognostic value of tumor size, metastases, extension into bone, and increased tumor marker in children with malignant sacrococcygeal germ cell tumors: A prospective evaluation of 71 patients treated in the german cooperative protocols maligne keimzelltumoren (makei) 83/86 and makei 89. J Clin Oncol $2003 ; 21 ; 781-786$.

12. Yao W, Li K, Diong K, Xiao X. Analysis of recurrence risks for sacrococcygeal teratoma in children. J Pediatr Surg 2014;49;1839-1842.

13. Rescorla FJ, Sawin RS, Coran AG, Dillon PW, Azizkhan RG. Long-term outcome for infants and children with sacrococcygeal teratoma: A report from the childrens cancer group. $J$ Pediatr Surg 1998;33;171-176.

14. de Corti F, Sarnacki S, Patte C et al. Prognosis of malignant sacrococcygeal germ cell tumors according to their natural history and surgical management. Surgical Oncology 2012;21;e31-e37.

15. Huddart S, Mann J, Robinson K et al. Sacrococcygeal teratomas: The uk children's cancer study group's experience. I. Neonatal. Pediatr Surg Int 2003;19;47-51.

16. Gurda GT, VandenBussche CJ, Yonescu R et al. Sacrococcygeal teratomas: Clinicopathological characteristics and isochromosome 12p status. Mod Pathol 2014;27;562-568.

17. Yoshida M, Matsuoka K, Nakazawa A et al. Sacrococcygeal yolk sac tumor developing after teratoma: A clinicopathological study of pediatric sacrococcygeal germ cell tumors and a 
proposal of the pathogenesis of sacrococcygeal yolk sac tumors. Journal of Pediatric Surgery $2013 ; 48 ; 776-781$.

18. Derikx J, De Backer A, van de Schoot L et al. Factors associated with recurrence and metastasis in sacrococcygeal teratoma. British Journal of Surgery 2006;93;1543-1548.

19. Simpson PJ, Wise KB, Merchea A et al. Surgical outcomes in adults with benign and malignant sacrococcygeal teratoma: A single-institution experience of 26 cases. Dis Colon Rectum 2014;57;851-857.

20. Ng EW, Porcu P, Loehrer PJ, Sr. Sacrococcygeal teratoma in adults: Case reports and a review of the literature. Cancer 1999;86;1198-1202.

21. Schneider DT, Schuster AE, Fritsch MK et al. Genetic analysis of mediastinal nonseminomatous germ cell tumors in children and adolescents. Genes Chromosomes Cancer $2002 ; 34 ; 115-125$.

22. Samaniego F, Rodriguez E, Houldsworth J et al. Cytogenetic and molecular analysis of human male germ cell tumors: Chromosome 12 abnormalities and gene amplification. Genes Chromosomes Cancer 1990;1;289-300.

23. Pienkowska-Grela B, Grygalewicz B, Bregula U. Overrepresentation of the short arm of chromosome 12 in seminoma and nonseminoma groups of testicular germ cell tumors. Cancer Genet Cytogenet 2002;134;102-108.

24. van Echten J, van Doorn LC, van der Linden HC, van der Veen AY, Burger CW, de Jong B. Cytogenetics of a malignant ovarian germ-cell tumor. Int J Cancer 1998;77;217-218.

25. Kraggerud SM, Szymanska J, Abeler VM et al. DNA copy number changes in malignant ovarian germ cell tumors. Cancer Res 2000;60;3025-3030. 
26. Sukov W, Cheville J, Giannini C et al. Isochromosome $12 \mathrm{p}$ and polysomy 12 in primary central nervous system germ cell tumors: Frequency and assoication with clinicopathologic features. Human Pathology 2010;41;232-238.

27. Hoffner L, Deka R, Chakravarti A, Surti U. Cytogenetics and origins of pediatric germ cell tumors. Cancer Genet Cytogenet 1994;74;54-58.

28. Bussey KJ, Lawce HJ, Olson SB et al. Chromosome abnormalities of eighty-one pediatric germ cell tumors: Sex-, age-, site-, and histopathology-related differences--a children's cancer group study. Genes Chromosomes Cancer 1999;25;134-146.

29. Chaganti RS, Rodriguez E, Mathew S. Origin of adult male mediastinal germ-cell tumours. Lancet 1994;343;1130-1132.

30. Perlman EJ, Hu J, Ho D, Cushing B, Lauer S, Castleberry RP. Genetic analysis of childhood endodermal sinus tumors by comparative genomic hybridization. J Pediatr Hematol Oncol 2000;22;100-105.

31. Perlman EJ, Cushing B, Hawkins E, Griffin CA. Cytogenetic analysis of childhood endodermal sinus tumors: A pediatric oncology group study. Pediatr Pathol 1994;14;695-708. 32. Miles RM, Stewart GS, Jr. Sacrococcygeal teratomas in adult. Ann Surg 1974;179;676683.

33. Harms D, Schmidt D, Leuschner I. Abdominal, retroperitoneal and sacrococcygeal tumours of the newborn and the very young infant. Report from the kiel paediatric tumour registry. Eur J Pediatr 1989;148;720-728.

34. Thurlbeck WM, Scully RE. Solid teratoma of the ovary. A clinicopathological analysis of 9 cases. Cancer 1960;13;804-811. 
35. Norris HJ, Zirkin HJ, Benson WL. Immature (malignant) teratoma of the ovary: A clinical and pathologic study of 58 cases. Cancer 1976;37;2359-2372.

36. Poulos C, Cheng L, Zhang S, Gersell DJ, Ulbright TM. Analysis of ovarian teratomas for isochromosome 12p: Evidence supporting a dual histogenetic pathway for teratomatous elements. Mod Pathol 2006;19;766-771.

37. Cossu-Rocca P, Zhang S, Roth LM et al. Chromosome 12p abnormalities in dysgerminoma of the ovary: A fish analysis. Mod Pathol 2006;19;611-615.

38. Busch C, Oppitz M, Wehrmann M, Schweizer P, Drews U. Immunohistochemical localization of nanog and oct4 in stem cell compartments of human sacrococygeal teratomas. Histopathology 2008;52;717-730.

39. Drut R. Immunohistochemical localization of nanog and oct4 in stem cell compartments of human and sacrococcygeal teratomas. Histopathology 2009;54;763-779.

40. Sen G, Sebire N, Olsen O, Kiely E, Levitt G. Familial currarino syndrome presenting with peripheral neuroectodermal tumour arising with a sacral teratoma. Pediatr Blood Cancer 2008;50;172-175.

41. Dundar M, Uzak A, Erdogan M et al. Partial trisomy 3q in a child with sacrococcygeal teratoma and cornelia de lange syndrome phenotype. Genetic Councelling 2011;22;199-205.

42. De Backer A, Madern G, Hakvoort-Cammel F, Heantjens P, Oosterhuis J, Hazebroek F. Study of the factors associated with recurrence in children with sacrococcygeal teratoma. $J$ Pediatr Surg 2006;41;173-181.

43. Elli M, Pinarli F, Kandemir B, Dagdemir A, Ceyhan M, Acar S. Sacrococygeal teratoma with sarcomatous differentiation in a child. Pediatric Hematology and Oncology 2008;25;345350. 
44. Ma Y, Zheng J, Zhu H et al. Sacrococcygeal teratoma with nephroblatic elements: A case report and review of the literature. Int J Clin Exp Pathol 2014;7;8211-8216.

45. Busse C, Nazeer T, Kanwar V, Wolden S, LaQuaglia M, Rosenblum M. Sacrococcygeal immature teratoma with malignant ependymoma component. Pediatr Blood Cancer $2009 ; 53 ; 680-681$.

46. Unal E, Koksal Y, Toy H, Gunel E, Acikgozoglu S. Neuroblastoma arising from an unresected sacrococcygeal teratoma in a child. J Pediatr Hematol Oncol 2010;32;233-235. 47. Yoshida M, Tanaka M, Gomi K et al. Malignant steroidogenic tumor arising from sacrococcygeal mature teratoma. Human Pathology 2011;42;1568-1572.

48. Arazi M, Toy H, Tavli L. Primary neuroendocrine carcinoma arising within a sacrococcygeal teratoma. Orthopedics 2007;30;878-879.

49. Golas M, Gunawan B, Raab B, Füzesi L, Lange B. Malignant transformation of an untreated congential sacrococcygeal teratoma: A amplification at $8 \mathrm{q}$ and $12 \mathrm{p}$ detected by comparative genomic hybridization. Cancer Genetics and Cytogenetics 2010;197;95-98.

50. McKenney J, Longacre T. Low-grade mucinous epithelial neoplasm (intestinal type) arising in mature sacrococcygeal teratoma with late recurrence as pseudomyxoma peritonei. Human Pathology 2008;39;629-632.

51. Cheng L, Zhang S, MacLennan G et al. Interphase fluorescence in situ hybridization analysis of chromosome $12 \mathrm{p}$ abnormalities is useful for distinguishing epidermid cysts of the testis from pure mature teratoma. Clin Cancer Res 2006;12;5668-5672.

52. Zhang C, Berney D, Hirsch M, Cheng L, Ulbright T. Evidence supporting the existence of benign teratomas of the postpubertal testis: A clinical, histopatologic, and molecular genetic analysis of 25 cases. Am J SUrg Pathol 2013;37;827-835. 


\section{Figure Legends}

Figure 1: Mature teratoma with glial (1A), ciliated and enteric-type glandular epithelium (1B), and squamous epithelium (1C). FISH analysis (1D) shows two paired red and green signals per nucleus, indicating two intact copies of chromosome 12.

Figure 2: Tumor with mature teratoma (2A), immature teratoma (2C), and yolk sac tumor components (2E). FISH analysis demonstrates green-red-green signals indicating an $\mathrm{i}(12 \mathrm{p})$ in the mature teratoma (2B), immature teratoma (2D), and yolk sac tumor components (2F). 
Table 1. Clinicopathologic summary of sacrococcygeal teratomas in both pre- and postpubertal patients

\begin{tabular}{|c|c|c|c|c|c|c|c|}
\hline Patient & Sex & Age & $\begin{array}{c}\text { Teratoma } \\
\text { Grade }\end{array}$ & Other GCT & i(12p) & $\begin{array}{c}\text { Duration of } \\
\text { F/U } \\
\text { (months) }\end{array}$ & F/U Status \\
\hline \multicolumn{8}{|c|}{ Pediatric cases } \\
\hline 1 & $\mathrm{~F}$ & $1 d$ & 0 & None & Neg & N/A & N/A \\
\hline 2 & $\mathrm{~F}$ & $1 d$ & 0 & None & Neg & 198 & Alive, NED \\
\hline 3 & $\mathrm{~F}$ & $2 d$ & 0 & None & Neg & N/A & N/A \\
\hline 4 & $\mathrm{~F}$ & $2 d$ & 0 & None & Neg & 163 & Alive, NED \\
\hline 5 & $\mathrm{~F}$ & $2 d$ & 0 & None & Neg & $\mathrm{N} / \mathrm{A}$ & N/A \\
\hline 6 & $F$ & $2 d$ & 0 & None & $\mathrm{Neg}$ & N/A & N/A \\
\hline 7 & $\mathrm{~F}$ & $2 d$ & 1 & None & $\mathrm{Neg}$ & N/A & N/A \\
\hline 8 & $\mathrm{~F}$ & $2 d$ & 1 & None & $\mathrm{Neg}$ & 142 & Alive, NED \\
\hline 9 & $\mathrm{~F}$ & $2 d$ & 2 & None & Neg & $\mathrm{N} / \mathrm{A}$ & N/A \\
\hline 10 & $\mathrm{~F}$ & $2 d$ & 3 & $\begin{array}{l}\text { YST and } \\
\text { PNET }\end{array}$ & Pos & 136 & Alive, NED \\
\hline 11 & $\mathrm{~F}$ & $4 d$ & 0 & None & Neg & N/A & N/A \\
\hline 12 & $\mathrm{~F}$ & $4 d$ & 0 & None & Neg & N/A & N/A \\
\hline 13 & $\mathrm{~F}$ & $4 d$ & 0 & None & Neg & N/A & N/A \\
\hline 14 & $\mathrm{~F}$ & $5 d$ & 0 & None & $\mathrm{Neg}$ & 77 & Alive, NED \\
\hline 15 & $\mathrm{~F}$ & $5 d$ & 3 & None & Neg & 21 & Alive, NED \\
\hline 16 & $\mathrm{~F}$ & $7 d$ & 0 & None & Neg & 140 & Alive, NED \\
\hline 17 & $F$ & $12 d$ & 2 & None & Neg & 59 & Alive, NED \\
\hline 18 & $\mathrm{~F}$ & $2 w$ & 0 & None & Neg & 136 & Alive, NED \\
\hline 19 & $\mathrm{~F}$ & $3 w$ & 0 & YST & Pos & 7 & Recurred \\
\hline 20 & $\mathrm{~F}$ & $4 w$ & 0 & None & Neg & 4 & Alive, NED \\
\hline 21 & $\mathrm{~F}$ & $6 w$ & 0 & None & Neg & 4 & Alive, NED \\
\hline
\end{tabular}




\begin{tabular}{|c|c|c|c|c|c|c|c|}
\hline 22 & $F$ & $6 w$ & 0 & None & Neg & N/A & $\mathrm{N} / \mathrm{A}$ \\
\hline 23 & $\mathrm{~F}$ & $8 w$ & 0 & None & Neg & 48 & Alive, NED \\
\hline 24 & $\mathrm{~F}$ & $9 w$ & 0 & None & Neg & 90 & Alive, NED \\
\hline 25 & $F$ & $3 m$ & 0 & None & Neg & 243 & Alive, NED \\
\hline 26 & $F$ & $3 m$ & 3 & None & Neg & 199 & Alive, NED \\
\hline 27 & $F$ & $4 m$ & 0 & None & Neg & N/A & N/A \\
\hline 28 & $F$ & $5 m$ & 0 & None & Neg & $\mathrm{N} / \mathrm{A}$ & $\mathrm{N} / \mathrm{A}$ \\
\hline 29 & $F$ & $7 m$ & 1 & YST & Pos & 94 & Alive, NED \\
\hline 30 & $F$ & $1 y$ & 0 & None & Neg & - & - \\
\hline 30 & $F$ & $1 y$ & 0 & None & Neg & 188 & $\begin{array}{c}\text { Recurred } 8 \\
\text { months later } \\
\text { but now Alive, } \\
\text { NED }\end{array}$ \\
\hline 31 & $F$ & $1 y$ & 0 & None & Neg & 233 & Alive, NED \\
\hline 32 & $F$ & $1 y$ & 0 & None & Neg & $\mathrm{N} / \mathrm{A}$ & $\mathrm{N} / \mathrm{A}$ \\
\hline 33 & $F$ & $1 y$ & 0 & YST & Pos & 15 & Alive \\
\hline 34 & $F$ & $1 y$ & 0 & None & Neg & 52 & Alive, NED \\
\hline 35 & $\mathrm{M}$ & $\begin{array}{c}\text { 16w GA } \\
\text { fetus }\end{array}$ & 3 & None & Neg & N/A & N/A \\
\hline 36 & $M$ & $1 d$ & 0 & None & Neg & N/A & $\mathrm{N} / \mathrm{A}$ \\
\hline 37 & $M$ & $2 d$ & 3 & None & Neg & 228 & Alive, NED \\
\hline 38 & $\mathrm{M}$ & $4 d$ & 0 & None & Neg & 81 & Alive, NED \\
\hline 39 & $M$ & $4 d$ & 0 & None & Neg & 254 & Alive, NED \\
\hline 40 & $M$ & $11 d$ & 0 & None & Neg & 59 & Alive, NED \\
\hline 41 & $M$ & $2 w$ & 0 & None & Neg & - & - \\
\hline 41 & $M$ & $6 \mathrm{~m}$ & 0 & None & Neg & 147 & $\begin{array}{l}\text { Recurred after } \\
6 \text { months but } \\
\text { now Alive, NED }\end{array}$ \\
\hline
\end{tabular}




\begin{tabular}{|c|c|c|c|c|c|c|c|}
\hline 42 & $M$ & $3 w$ & 0 & None & Neg & 139 & Alive, NED \\
\hline 43 & $M$ & $4 w$ & 0 & None & Neg & $\mathrm{N} / \mathrm{A}$ & $\mathrm{N} / \mathrm{A}$ \\
\hline 44 & $M$ & $4 w$ & 1 & None & Neg & 35 & Alive, NED \\
\hline 45 & $M$ & $8 m$ & 0 & None & Neg & N/A & N/A \\
\hline 46 & $M$ & $1 y$ & 0 & None & Neg & N/A & N/A \\
\hline 47 & $M$ & $6 y$ & 0 & None & Neg & 77 & Alive, NED \\
\hline 48 & $M$ & $8 y$ & 0 & None & Neg & 95 & Alive, NED \\
\hline \multicolumn{8}{|c|}{ Adult cases } \\
\hline 49 & $F$ & $35 y$ & 0 & None & Neg & 82 & Alive, NED \\
\hline 50 & $F$ & $35 y$ & 0 & None & Neg & $\mathrm{N} / \mathrm{A}$ & $\mathrm{N} / \mathrm{A}$ \\
\hline 51 & $F$ & $50 y$ & 0 & None & Neg & 180 & Alive, NED \\
\hline 52 & $M$ & $22 y$ & 0 & None & $\mathrm{Neg}$ & $\mathrm{N} / \mathrm{A}$ & $\mathrm{N} / \mathrm{A}$ \\
\hline
\end{tabular}


Table 2. Summary of 52 patients (54 specimens) with sacrococcygeal teratoma.

\begin{tabular}{|c|c|c|}
\hline & Pediatric patients (48) & Adult patients (4) \\
\hline Female: Male Ratio & $2.4: 1$ & $3: 1$ \\
\hline $\begin{array}{l}\text { Age } \\
\text { Range } \\
\text { Median }\end{array}$ & $\begin{array}{l}0-8 \text { years } \\
2 \text { weeks }\end{array}$ & $\begin{array}{l}22-50 \text { years } \\
35 \text { years }\end{array}$ \\
\hline $\begin{array}{l}\text { Pathology and i(12p) status } \\
\text { Teratoma (without YST), } \\
\text { G0 } \\
\text { Teratoma (without YST), } \\
\text { G1 } \\
\text { Teratoma (without YST), } \\
\text { G2 } \\
\text { Teratoma (without YST), } \\
\text { G3 } \\
\text { Teratoma and yolk sac } \\
\text { tumor }\end{array}$ & $\begin{array}{l}35(0 \% \mathrm{i}(12 \mathrm{p})) \\
3(0 \% \mathrm{i}(12 \mathrm{p})) \\
2(0 \% \mathrm{i}(12 \mathrm{p})) \\
4(0 \% \mathrm{i}(12 \mathrm{p})) \\
4(100 \% \mathrm{i}(12 \mathrm{p}))\end{array}$ & $4(0 \% \mathrm{i}(12 \mathrm{p}))$ \\
\hline $\begin{array}{l}\text { Outcome } \\
\text { No evidence of disease } \\
\text { Alive (status unknown) } \\
\text { Recurrent } \\
\text { Not available }\end{array}$ & $\begin{array}{l}28^{*} \\
1 \\
1 \\
18\end{array}$ & 2 \\
\hline Mean follow up (range) & 8.9 years (4-254 months) & 10.9 years ( $82-180$ months) \\
\hline
\end{tabular}

*Including 2 with recurrence and second excision with NED at 147 and 188 months follow up. YST: yolk sac tumor. 

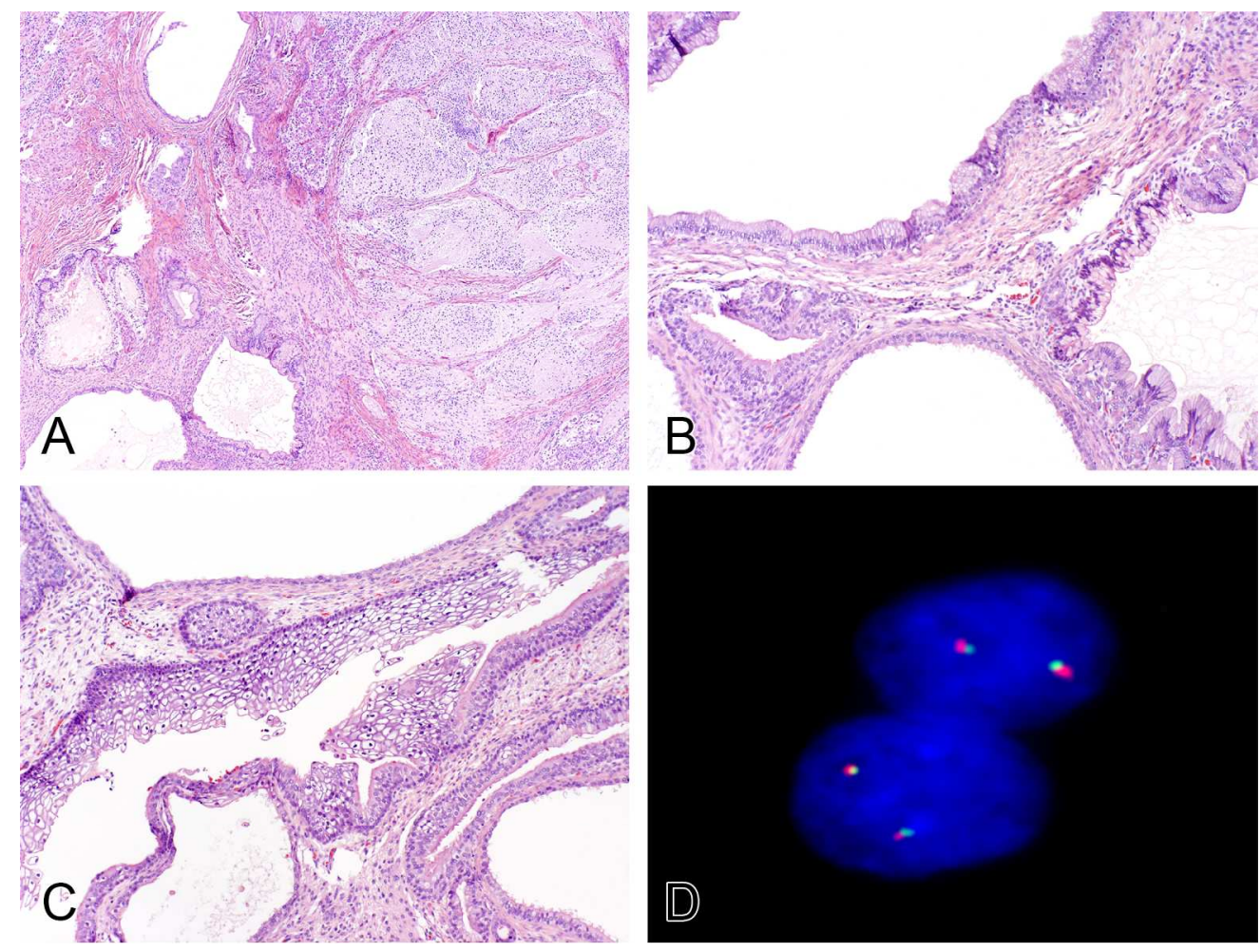

Figure 1

$206 \times 155 \mathrm{~mm}(300 \times 300$ DPI $)$ 


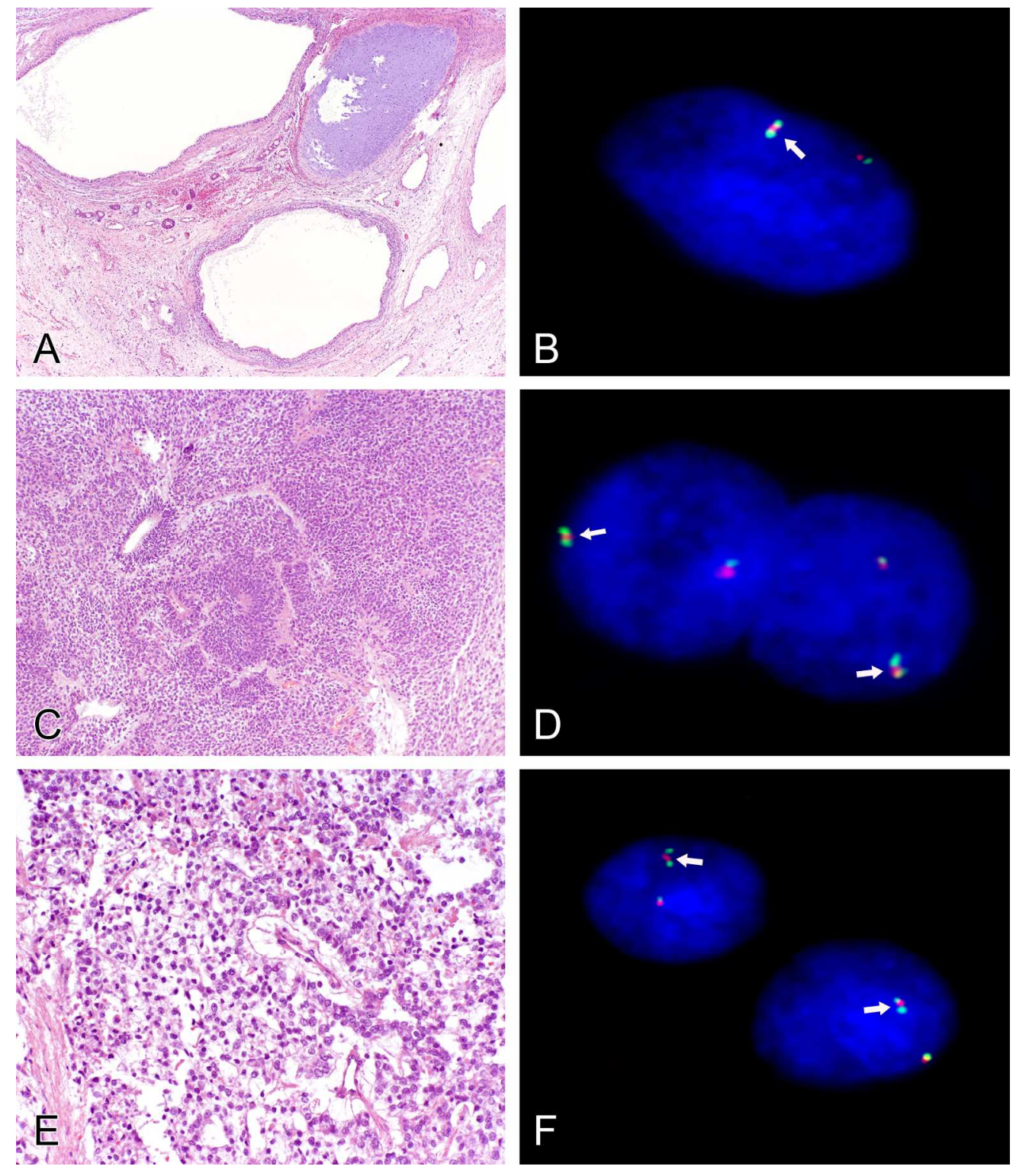

Figure 2

$206 \times 240 \mathrm{~mm}$ (300 x 300 DPI) 